\title{
$\mathrm{PSRC}$ 합성기둥의 반복가력 실험
}

\author{
황 현 종 ${ }^{1} \cdot$ 엄 태 성 ${ }^{2 *} \cdot$ 박 홍 근 $^{3)} \cdot$ 이 창 남 ${ }^{4)} \cdot$ 김 형 섭 ${ }^{5)}$ \\ 1) 박사과정, 서울대학교, 건축학과 ${ }^{2)}$ 조교수, 단국대학교, 건축공학과 ${ }^{3)}$ 교수, 서울대학교, 건축학과 \\ 4) 대표이사, (주)센구조연구소 ${ }^{5)}$ 소장, (주)센구조연구소
}

\section{Cyclic Loading Tests for Prefabricated Composite Columns Using Steel Angle and Reinforcing Bar}

\author{
Hwang, Hyeon Jong ${ }^{1)} \quad$ Eom, Tae Sung ${ }^{2) *} \quad$ Park, Hong Gun ${ }^{3)}$ \\ Lee, Chang $\mathrm{Nam}^{4} \quad$ Kim, Hyoung Seop ${ }^{5)}$ \\ 1) Ph.D., Candidate, Dept. of Architecture \& Architectural Engineering, Seoul National University, Seoul, 151-744, Korea \\ 2) Assistant Professor, Dept. of Architectural Engineering, Dankook University, Gyeonggi-do, 448-701, Korea \\ 3) Professor, Dept. of Architecture \& Architectural Engineering, Seoul National University, Seoul, 151-744, Korea \\ 4) CEO, Sen Structural Engineers Co. Ltd, Seoul, 150-808, Korea \\ 5) Engineer, Sen Structural Engineers Co. Ltd, Seoul, 150-808, Korea
}

ABSTRACT : PSRC composite column is a concrete encased steel angle column. In the PSRC composite column, the steel angles placed at the corner of the cross-section resists bending moment and compression load. In the present study, using the performance criteria in KBC 2009, cyclic lateral loading test was performed for PSRC columns to verify the seismic performance. The test parameters were the column type, the use of continuous hoop, and the use of studs for steel angle. $2 / 3$ scale specimens of a conventional composite column and three PSRC columns were tested. The test results showed that the load-carrying capacity predicted by KBC 2009 correlated well with the test results. The specimens also exhibited good deformation and energy dissipation capacities. After concrete cover spalling under cyclic loading, the load-carrying capacity were decreased by buckling of longitudinal bars and steel angles. When continuous hoop was used, the deformability of the PSRC column was improved, preventing early buckling of the steel angles.

KEYWORDS : PSRC composite column, angle, continuous hoop, prefabrication, seismic performance test

\section{1. 서 론}

고층건물을 중심으로 압축저항성능을 향상시키기 위하여 단면 중심에 $\mathrm{H}$ 형강을 매입한 $\mathrm{SRC}$ 합성기둥이 널리 사용되 어 왔다. 하지만, 합성기둥의 휨저항성능을 높이기 위해서는 강재를 최대한 기둥 단면의 모서리에 배치하는 것이 효과적

Note.-Discussion open until June 30, 2014. This manuscript for this paper was submitted for review and possible publication on July 15 , 2013; revised October 16, 2013; approved on October 28, 2013. (c) KSSC 2013

\section{* Corresponding author}

Tel. +82-31-8005-3731 Fax. +82-31-8021-7225

E-mail: tseom@dankook.ac.kr
이다 ${ }^{[1]}$. 대표적으로 김형근 등 ${ }^{[2]}$, 김보람 등 ${ }^{[3]}$, Campione ${ }^{[4]}$, Montuori 등 ${ }^{[5]}$, 황현종 등 ${ }^{[6]}$, 엄태성 등 $^{[7]}$, 김창수 등 ${ }^{[8]}$ 은 앵글을 기둥 단면의 모서리에 배치하는 새로운 합성기둥 상 세를 제안하였다. Fig. 1은 H형강 대신 앵글을 사용하는 PSRC 합성기둥(Prefabricated Steel- Reinforced Concrete column $)^{[6],[7]}$ 의 두 가지 상세를 보여준다. PSRC 합성기둥 은 앵글을 직사각형 단면의 네 코너에 배치하고, 각 앵글은 직각방향의 철근타이(tie bar), 강판(tie plate), 연속후프 (continuous hoop) ${ }^{[9]}$ 등으로 용접하여 자립시킨다. 구조적 으로 PSRC 합성기둥은 앵글을 기둥 단면 네 코너에 배치하 기 때문에 H형강을 단면 중심에 배치하는 기존 $\mathrm{SRC}$ 합성기 둥에 비해서 강재량이 동일하더라도 휨에 대한 강성 및 강도 가 더 높다 ${ }^{[7]}$. 또한, 철구공장에서 앵글과 철근을 조립하여 


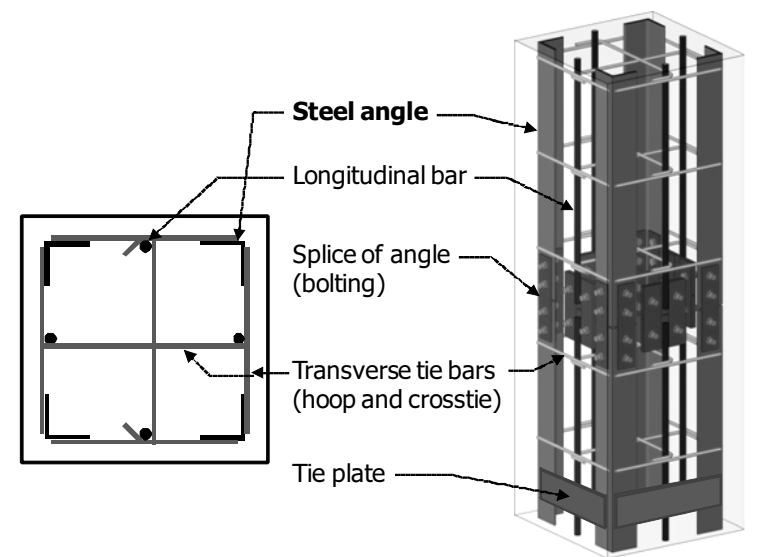

(a) PSRC composite column

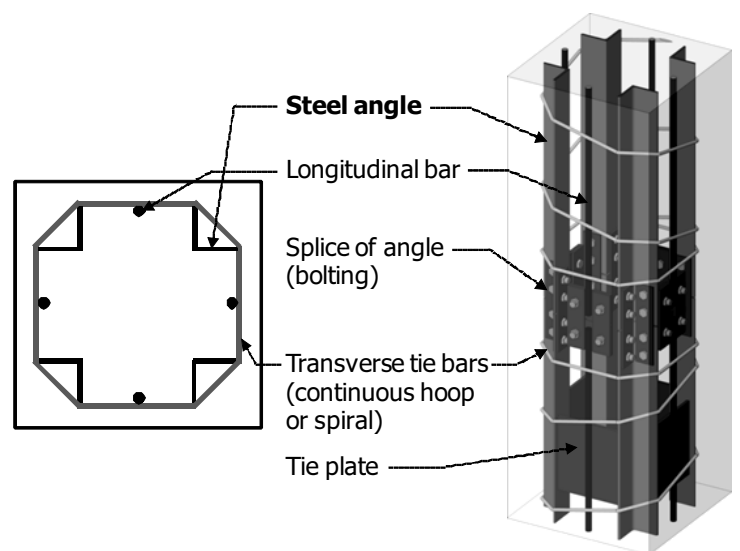

(b) PSRC composite column using continuous hoop

Fig. 1 Composite columns using steel angles

일체화하기 때문에 현장에서 철근 작업이 생략되며, $\mathrm{RC}$ 보와 접합시 접합부에서 보 철근이 PSRC 합성기둥을 관통할 수 있기 때문에 접합부의 일체화가 가능하다. Fig. 1(b)와 같이 연속후프를 사용하여 횡보강할 경우 철근콘크리트 기둥의 나 선철근 횡보강과 같이 압축과 휨(또는 중력하중과 지진하중) 에 대한 우수한 연성확보가 가능하다 ${ }^{[9]}$.

황현종 ${ }^{[6]}$, 엄태성 ${ }^{[7]}$ 등의 실험연구를 따르면, PSRC 합성 기둥의 압축 및 휨 저항성능이 현행 설계기준 ${ }^{[10],\{11]}$ 을 만족 하지만, 비탄성 변형이 증가할 경우 앵글을 둘러싸는 피복 콘 크리트의 조기 파괴, 앵글과 콘크리트 사이의 부착 파괴, 앵 글-타이철근 용접부에서의 앵글 인장파단 등에 취약할 수 있 다. 따라서 PSRC 합성기둥을 중간 및 특수모멘트골조 등과 같은 내진구조에 사용하기 위해서는, 반복하중을 경험하는 PSRC 합성기둥에 대하여 변형능력, 에너지소산능력 등 내진 성능에 대한 추가 검증이 필요하다.

본 연구에서는 PSRC 합성기둥의 내진성능을 검증하기 위 하여, $2 / 3$ 스케일을 갖는 세 개의 PSRC 합성기둥과 한 개 의 기존 $\mathrm{SRC}$ 합성기둥 대조실험체에 대하여 압축력 재하 후 횡방향으로 반복가력 실험을 수행하였다. 이를 통하여 PSRC 합성기둥의 하중재하능력, 변형능력, 에너지 소산능력, 파괴
특성 등 내진성능을 검증하였다.

\section{2. 실험 계획}

\section{1 실험체 계획}

본 연구에서는 $2 / 3$ 으로 축소 제작된 기존 $\mathrm{SRC}$ 합성기둥 실험체 $\mathrm{S} 1$ 과 PSRC 합성기둥 실험체 $\mathrm{S} 2, \mathrm{~S} 3, \mathrm{~S} 4$ 에 대하여 횡하중 반복재하 실험을 수행하였다. Table 1과 Fig. 2는 각각 실험체의 실험변수와 상세도면을 보여준다. 주요 실험변 수는 강재단면 종류(H형강 및 앵글조립), 직각방향 타이 철 근(용접후프 및 연속후프), 앵글-콘크리트 부착 방법(용접후 프 및 스터드)이다. SRC 합성기둥 및 $\mathrm{PSRC}$ 합성기둥 실험 체들은 $\mathrm{KBC} 2009^{[10]}$ 강구조 설계기준 및 $\mathrm{AISC} 360^{[11]}$ 을 바탕으로 설계하였다. 또한 PSRC 합성기둥의 앵글-콘크리트 부착강도, 전단강도, 타이철근 용접부 강도 등은 엄태성 등 ${ }^{[7]}$ 에 제시된 방법을 사용하여 검토하였다.

Fig. 2 에 나타낸 바와 같이 모든 실험체는 동일한 크기의 기둥 $(400 \mathrm{~mm} \times 400 \mathrm{~mm} \times 1,800 \mathrm{~mm})$ 과 기둥 기초 $(900 \mathrm{~mm} \times$ $1,400 \mathrm{~mm} \times 550 \mathrm{~mm})$ 를 갖도록 제작하였다. 기존 $\mathrm{SRC}$ 합성

Table 1. Test parameters

\begin{tabular}{|c|c|c|c|c|}
\hline Specimens & S1 & $\mathrm{S} 2$ & S3 & S4 \\
\hline $\begin{array}{l}\text { Column cross-section }(\mathrm{mm} \times \mathrm{mm}) \\
\text { Concrete strength }(\mathrm{MPa}) \\
\text { Steel section }(\mathrm{mm}) \\
\text { Yield strength / Ultimate strength / Elongation at failure } \\
(\mathrm{MPa}, \%) \\
\text { Longitudinal re-bar } \\
\text { Yield strength / Ultimate strength / Elongation at failure } \\
(\mathrm{MPa}, \%) \\
\text { Transverse tie bars } \\
\text { Yield strength / Ultimate strength / Elongation at failure } \\
(\mathrm{MPa}, \%)\end{array}$ & $\begin{array}{c}400 \times 400 \\
23.3 \\
\mathrm{H}-150 \times 150 \times 6 \times 9 \\
402 / 577 / \\
21.0 \\
4-\mathrm{D} 19 \\
520 / 629 / \\
18.7 \\
\mathrm{D} 13 @ 150 \\
518 / 646 / \\
18.3\end{array}$ & $\begin{array}{c}400 \times 400 \\
23.3 \\
\mathrm{~L}-75 \times 75 \times 6 \\
477 / 535 / \\
17.5 \\
4-\mathrm{D} 19 \\
520 / 629 / \\
18.7 \\
\mathrm{D} 13 @ 150 \\
518 / 646 / \\
18.3\end{array}$ & $\begin{array}{c}400 \times 400 \\
23.3 \\
\mathrm{~L}-75 \times 75 \times 6 \\
477 / 535 / \\
17.5 \\
4-\mathrm{D} 19 \\
520 / 629 / \\
18.7 \\
\mathrm{D} 13 @ 150 \\
518 / 646 / \\
18.3\end{array}$ & $\begin{array}{c}400 \times 400 \\
23.3 \\
\mathrm{~L}-75 \times 75 \times 6 \\
477 / 535 / \\
17.5 \\
4-\mathrm{D} 19 \\
520 / 629 / \\
18.7 \\
\mathrm{D} 13 @ 150 \\
518 / 646 / \\
18.3\end{array}$ \\
\hline
\end{tabular}



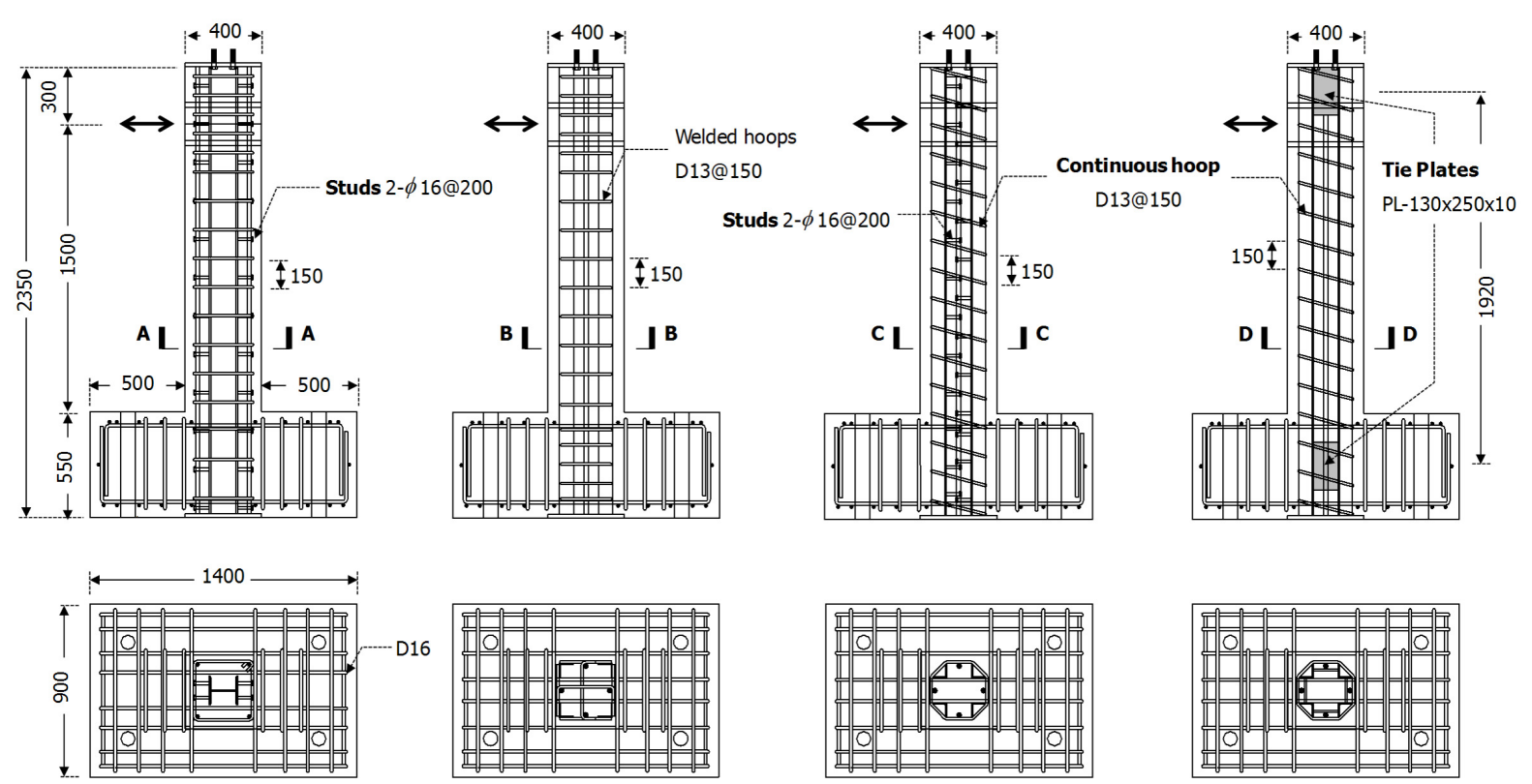

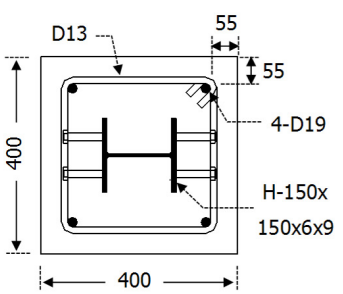

Section A-A

(a) S1

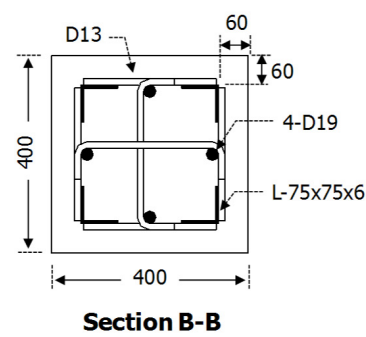

(b) S2

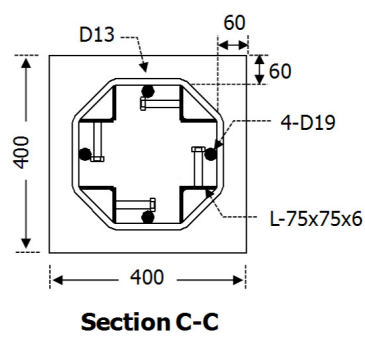

(c) 53

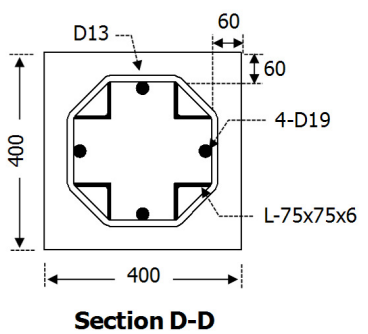

(d) $\mathrm{S} 4$

Fig. 2 Dimensions and details of test specimens $(\mathrm{mm})$

기둥 실험체 S1은 단면 중앙부에 SM490 H형강 $(\mathrm{H}-150$ $\times 150 \times 6 \times 9$, 강재비 $A_{s} / A_{g}=2.2 \%, A_{s}=$ 단면에 사용된 강재의 총 단면적, $A_{g}=$ 기둥 단면의 총 단면적)을 배치하고 단면의 네 모서리에 SD400W 4-D19 철근을 길이방향으로 배치하였다(Fig. 2(a)의 A-A 단면 참조). 심부 콘크리트 횡 보강 및 전단보강을 위하여, 직각방향 보강근으로 $\mathrm{SD} 400 \mathrm{~W}$ $\mathrm{D} 13$ 후프를 $150 \mathrm{~mm}$ 간격으로 배치하였다. $\mathrm{H}$ 형강과 콘크리 트 사이의 부착성능 확보를 위하여 $\mathrm{H}$ 형강 플랜지 양면에 $\phi$ 16 스터드를 2 개씩 $200 \mathrm{~mm}$ 간격으로 배치하였다.

$\mathrm{PSRC}$ 합성기둥 실험체 $\mathrm{S} 2$ 는 단면의 네 모서리에 $\mathrm{SM} 490$ 앵글 4 개 $\left(4-\mathrm{L}-75 \times 75 \times 6, A_{s} / A_{g}=2.2 \%\right)$ 와 앵글 사이마다 $\mathrm{SD} 400 \mathrm{~W}$ 4-D19 철근을 길이방향으로 배치하였다(Fig. 2 (b)의 B-B 단면 참조). 직각방향 보강근으로 $\mathrm{D} 13$ 철근도막 (길이 270mm) 4개를 용접하여 앵글을 감싸는 용접후프를 설치하였고, 또한 길이방향 주철근 4-D19를 연결하는 2 개의 교차띠철근(cross tie)을 십자형으로 배치하였다. 직각방향 용접후프 및 띠철근의 간격은 합성기둥 전단요구 및 앵글-콘 크리트 부착요구를 확보하도록 이전 연구 ${ }^{[7]}$ 의 제안식을 사용 하여 $150 \mathrm{~mm}$ 로 결정하였다.
PSRC 합성기둥 실험체 S3과 S4는 연속후프를 사용하여 횡보강한 실험체로서, 앵글-콘크리트 부착성능 증진 및 연속 후프 시공성 개선을 위하여 단면 모서리의 앵글 배치 방향을 변경하였다(Fig. 2의 C-C, D-D 단면 참조). 단면 모서리에 서 연속후프와 앵글 사이의 유격이 최소화되도록, 팔각형 형 태로 제작된 연속후프를 가용접(tag welding)으로 앵글에 고정시키며 앵글을 감ㅆㅆㅆㄷㅏ. S2와 동일하게 S3 및 $\mathrm{S} 4$ 실험체 모두 연속후프의 간격으로 $150 \mathrm{~mm}$ 를 사용하였다. S3와 S4 모두 길이방향 주철근으로 $\mathrm{SD} 400 \mathrm{~W}$ 4-D19를 추가로 배치 하였다.

$\mathrm{S} 3$ 은 앵글의 부착강도 확보를 위하여 $\phi 16$ 스터드를 200 $\mathrm{mm}$ 간격으로 배치하였다(Fig. 2(c)의 C-C 단면 참조). 이 와 달리, $\mathrm{S} 4$ 의 경우 스터드를 직접 앵글에 설치하지 않는 대 신 기초와 기둥 상부에 8개의 타이강판 SM490 PL-130x $250 \times 10$ 을 용접하여 앵글-콘크리트 부착상세를 단순화하였 다. 즉, 휨에 인하여 단면의 좌·우 앵글에 각각 인장력 및 압축력이 작용하면, 기초 및 기둥 상부에만 설치한 타이강판 의 전단으로 좌·우 앵글의 인장력과 전단력을 전달한다. Fig. 2(d)에 나타낸 바와 같이 상 - 하 타이강판의 거리 $(=$ 
$1,920 \mathrm{~mm})$ 가 기둥 단면 깊이 $(=400 \mathrm{~mm})$ 대비 4 배 이상으 로 크기 때문에, 원칙적으로 앵글의 휨강성만으로는 위 메커 니즘이 성립되지 않는다. 하지만, 연속후프에 의하여 효과적 으로 횡보강된 콘크리트 내부에 앵글이 매입되어 있으며, 앵 글과 용접된 연속후프의 지압에 의한 부착저항이 앵글 길이 방향을 따라 연속적으로 작용하기 때문에 상 - 하 타이강판의 전단작용과 함께 앵글의 부착파괴를 억제할 수 있다(4.3 부 착성능 참조).

실험에 사용한 SM490 강재(H형강 및 앵글)와 SD400W 철근(D19 및 $\mathrm{D} 13)$ 의 항복강도와 연신률, 콘크리트 강도는 Table 1에 나타냈다. SRC 합성기둥에 적용한 SM490 H형 강의 경우 항복강도 $F_{y}=402 \mathrm{MPa}$, 인장강도 $F_{u}=577 \mathrm{MPa}$, 연신율은 $21.0 \%$ 이다. $\mathrm{PSRC}$ 합성기둥에 적용한 $\mathrm{SM} 490$ 앵 글의 경우 항복강도 $F_{y}=477 \mathrm{MPa}$, 인장강도 $F_{u}=535 \mathrm{MPa}$, 연신율은 $17.5 \%$ 이다. 길이방향 주철근으로 사용한 $\mathrm{SD} 400 \mathrm{~W}$ $\mathrm{D} 19$ 철근은 항복강도 $f_{y}=520 \mathrm{MPa}$, 인장강도 $f_{u}=629 \mathrm{MPa}$, 연신율은 $18.7 \%$ 이다. 직각방향 용접후프 및 연속후프로 사 용한 $\mathrm{SD} 400 \mathrm{~W} \mathrm{D} 13$ 철근은 항복강도 $f_{y}=518 \mathrm{MPa}$, 인장 강도 $f_{u}=646 \mathrm{MPa}$, 연신율은 $18.3 \%$ 이다. 여기서, 철근 및 강재는 강도는 1 축 인장 실험으로 구한 실제 항복강도 및 인 장강도를 나타낸다. 강판 및 철근 용접은 사르피노치인성 $86 \mathrm{~J} @ 0^{\circ} \mathrm{C}$ 을 만족하는 규격 YFW-C50DR 용접봉(인장강도 $\left.F_{E X X}=584 \mathrm{MPa}\right)$ 를 사용하였다. 실험체 가력시 계측한 콘 크리트 강도 $f_{c k}=23.3 \mathrm{MPa}$ 이다.

\section{2 실험 방법}

Fig. 3은 기둥 실험체의 반복가력실험을 위한 실험 셋팅 및 가력 방법을 나타낸다. 기둥 하부 위험단면으로부터 상부 엑츄에이터 중심까지의 기둥 전단경간은 $H_{e}=1,500 \mathrm{~mm}$ 이 다. 기둥 상부에 유압잭 두 개를 수직방향으로 설치하여 $N$ $=800 \mathrm{kN}$ 의 축력을 재하하였다. 횡하중은 기둥 상부에서 최 대 용량 $2,000 \mathrm{kN}$, 최대 스트로크 $\pm 250 \mathrm{~mm}$ 인 엑츄에이터를 사용하여 반복가력을 하였다. 횡변위비 (즉, 엑츄에이터 횡변 위를 기둥 전단경간으로 나눈 값 $\pm \pm 0.375 \%, \pm 0.5 \%, \pm 0.75 \%$ 에서 6 회 반복가력하였고, $\pm 1.0 \%$ 에서 4 회 반복가력하였으 며, 이후 $\pm 1.5 \%, 2.0 \%, 3.0 \%, 4.0 \%, 5.0 \%, 6.0 \%, 7.0 \%$ 에서 2회 반복가력하였다 ${ }^{[10],\{11]}$.

횡력 반복재하 실험 동안 변위계를 이용하여 실험체의 층 간변위를 계측하였으며, 변형률 게이지를 통하여 SRC 및 PSRC 합성기둥의 앵글, 철근 등의 변형률 이력을 계측하였다.

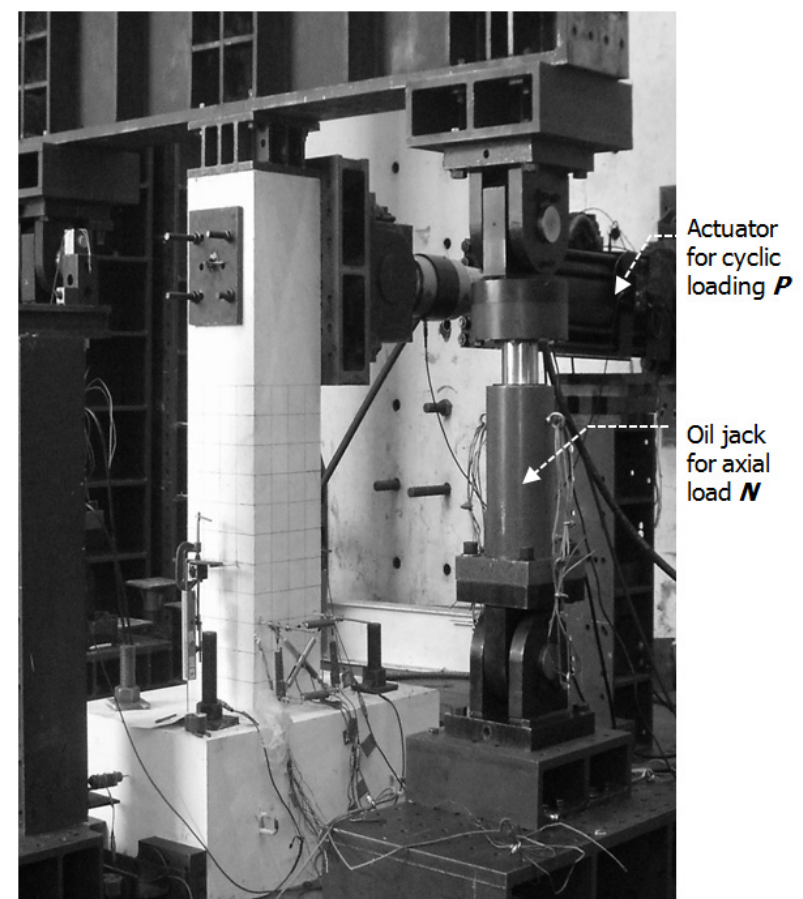

Fig. 3 Test Set-up of column specimens

\section{3. 실험 결과}

\section{1 히중-변위비 관계 및 파괴양상}

Fig. 4는 주기하중을 받는 실험체의 기둥 상부 횡하중 $(P)$ 과 횡변위비의 관계를 보여준다. Fig. 4(e)의 포락곡선 으로부터 구한 각 실험체의 정·부방향 최대강도 $P_{u}$, 항복 변위비 $\delta_{y}$, 최대변위비 $\delta_{u}$, 변위연성도 $\mu\left(=\delta_{u} / \delta_{y}\right)$ 를 계산 하여 Table 2에 정리하였다. 항복변위비 $\delta_{y}$ 는 최대강도의 $75 \%$ 를 지나는 할선강성이 최대하중에 도달하는 횡변위비로 정의하였고, 최대변위비 $\delta_{u}$ 는 최대강도 이후 하중재하능력이 최대강도의 $75 \%$ 로 저하되는 변위비로 정의하였다 (Fig. 4(f) 참조 ${ }^{[12]}$. Fig. 5는 각 실험체에 대하여 실험 중인 횡변위비 $3.0 \sim 4.0 \%$ 와 실험종료 후에 촬영한 기둥 하부 소성힌지의 균열 및 파괴 양상을 보여준다.

Fig. 4(a)와 Fig. 5(a)는 기존 SRC 합성기둥 S1의 실 험결과를 보여준다. 횡변위비 $2.0 \%$ 에서 최대강도 $P_{u}=202$ $\mathrm{kN}$ 에 도달한 이후 $6.0 \%$ 변위비까지 완만한 강도저하를 보 이며 안정적인 주기거동을 보였다. 이러한 강도저하는 압축력 으로 인한 이차효과에 의한 것으로 판단된다(4장 참조). 비 록 주기거동 동안 급격한 강도 및 강성저하가 발생하지 않았 지만, Fig. 5(a)에 보는 바와 같이 $3.0 \sim 4.0 \%$ 횡변위비에 서 휨-압축에 의하여 기둥 하단부에서 콘크리트 피복 파괴가 발생하였다. 그러나 단면 내부의 $\mathrm{H}$ 형강 웨브가 전단에 저항 

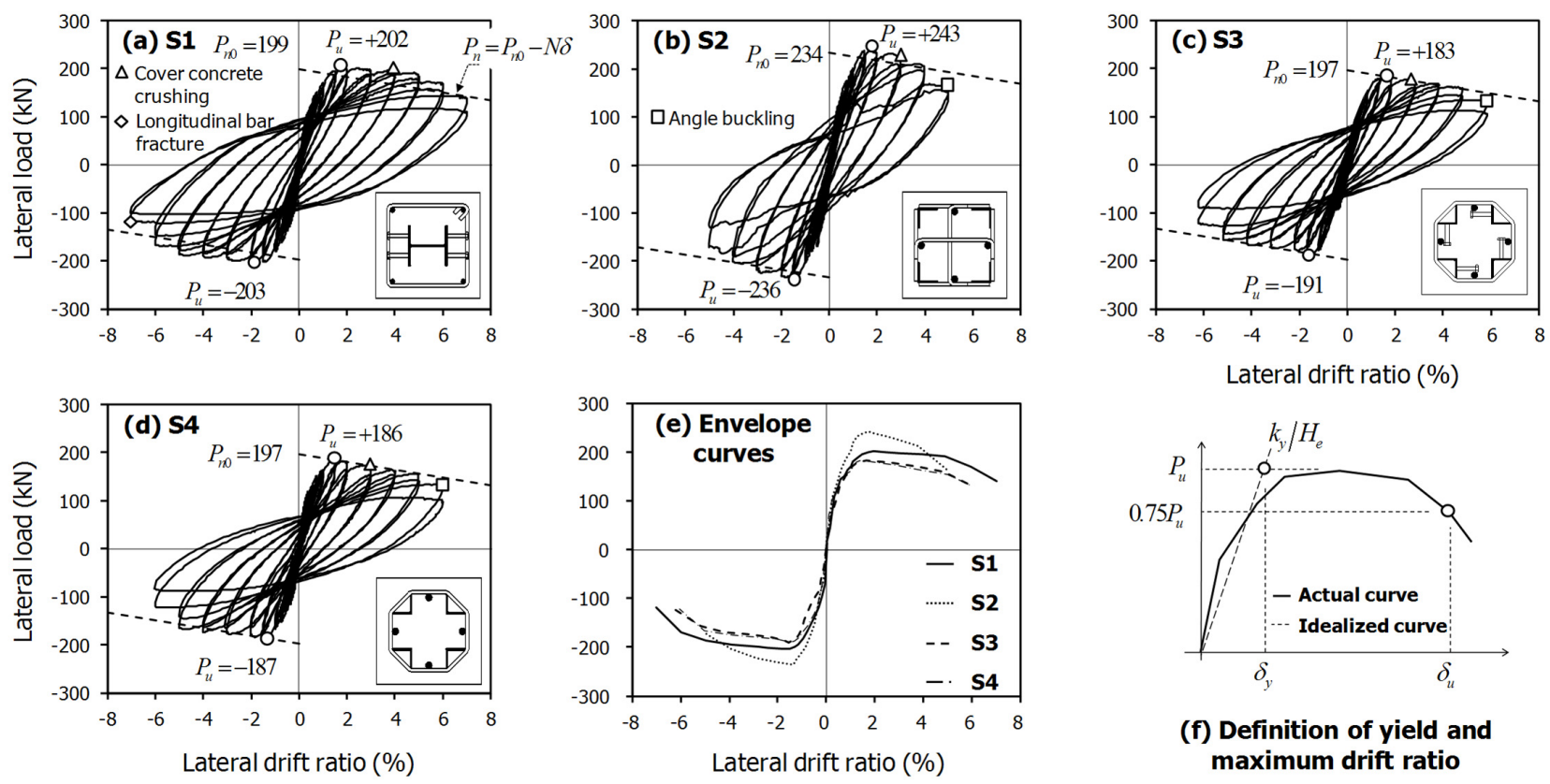

(f) Definition of yield and maximum drift ratio

Fig. 4 Lateral load-drift ratio relationships of specimens

하므로 대각방향의 전단균열이 크지 않았다. 이후 주근의 좌 굴로 인하여 콘크리트 피복이 완전히 파괴되었고, 결국 $7.0 \%$ 의 층간변위비에서 저주파 피로 파괴로 인한 기둥 주철 근의 파단이 발생하며 S1의 하중재하능력이 급격히 저하되었 다(Fig. 5(b) 참조).

$\mathrm{PSRC}$ 합성기둥 실험체 $\mathrm{S} 2$ 는 $2.0 \%$ 횡변위비에서 최대강 도 $P_{u}=243 \mathrm{kN}$ 에 도달하여 휨 및 전단균열이 크게 발생하 였고, Fig. 5(c)에 보는 바와 같이 3.0\% 변위비에서 기둥 하단부에서 휨-압축에 의하여 콘크리트 피복이 파괴되었다. $\mathrm{S} 2$ 는 직각방향 철근과 콘크리트에 의한 트러스 작용으로 전 단에 저항하고 또한 단면 모서리에 배치된 앵글의 효율적인 휨저항으로 인하여 기둥의 최대강도(또는 전단력)가 약 $20 \%$ 증가된 결과, $3.0 \sim 4.0 \%$ 의 층간변위비에서 직각방향으로부 터 약 $35^{\circ} \sim 60^{\circ}$ 방향의 전단균열이 복부 영역에서 큰 폭으로 나타났다. Fig. 5(d)에 나타낸 바와 같이, $5.0 \%$ 횡변위비에 서 기둥 하부의 소성힌지 영역에서 콘크리트 피복이 완전히
파괴되어 앵글 및 직각방향 철근이 노출되었고, 반복적인 인 장-압축 거동으로 인하여 주철근과 앵글의 좌굴이 시작되었 다. 앵글의 두 플랜지에서 모두 국부 좌굴이 발생하였지만, 직각방향 철근과 앵글의 용접부에서는 인장파단이 관찰되지 않았다. 대신 앵글 및 용접후프 철근으로 횡보강된 콘크리트 는 반복하중에 의한 X자형의 대각 전단균열과 앵글 좌굴 이 후의 과도한 휨-압축 작용으로 인하여 압괴가 발생하였다 (Fig. 5(d) 참조). 종국적으로 Fig. 4(b)에 보는 바와 같이 $\mathrm{S} 2$ 는 $5.0 \%$ 횡변위비에서 하중재하능력이 급격히 저하되어 파괴되었다.

연속후프로 횡보강한 $\mathrm{PSRC}$ 합성기둥 실험체 $\mathrm{S} 3$ 은 $2.0 \%$ 횡변위비에서 휨 및 전단균열(약 $\left.35^{\circ} \sim 55^{\circ}\right)$ 이 발생하였고, 기둥 하단부에서 휨-압축에 의한 피복 콘크리트의 파괴가 시 작되었다. Fig. 5(e)에 보는 바와 같이 $3.0 \%$ 횡변위비에서 기둥 하부에서 콘크리트 피복이 크게 파괴되었지만, 전단균열 의 폭은 $\mathrm{S} 2$ 에 비하여 현저히 줄어들었다. 이러한 콘크리트

Table 2. Summary of test results

\begin{tabular}{|c|c|c|c|c|c|c|c|c|c|c|c|c|}
\hline \multirow[t]{2}{*}{ Specimens } & \multicolumn{2}{|c|}{$\begin{array}{c}\text { Maximum strength } \\
P_{u}(\mathrm{kN}) \\
\end{array}$} & \multicolumn{2}{|c|}{$\begin{array}{c}\text { Yield drift ratio } \\
\delta_{y}(\%)\end{array}$} & \multicolumn{2}{|c|}{$\begin{array}{l}\text { Maximum drift } \\
\text { ratio } \delta_{u}(\%)\end{array}$} & \multicolumn{2}{|c|}{$\begin{array}{c}\text { Nominal strength } \\
P_{n 0}(\mathrm{kN}) \\
\end{array}$} & \multicolumn{2}{|c|}{$\begin{array}{c}\text { Yield stiffness } \\
k_{y}(\mathrm{kN} / \mathrm{mm})\end{array}$} & \multicolumn{2}{|c|}{$\begin{array}{l}\text { Ductility } \\
\mu\left(=\delta_{u} / \delta_{y}\right)\end{array}$} \\
\hline & Positive & Negative & Positive & Negative & Positive & Negative & Method $1^{1)}$ & Method $2^{2)}$ & Positive & Negative & Positive & Negative \\
\hline $\begin{array}{l}\text { S1 } \\
\text { S2 } \\
\text { S3 } \\
\text { S4 }\end{array}$ & $\begin{array}{l}202 \\
243 \\
183 \\
186\end{array}$ & $\begin{array}{l}-203 \\
-236 \\
-191 \\
-187\end{array}$ & $\begin{array}{l}0.98 \\
1.00 \\
0.85 \\
0.80\end{array}$ & $\begin{array}{l}-0.93 \\
-0.96 \\
-1.17 \\
-0.85\end{array}$ & $\begin{array}{l}6.01 \\
3.98 \\
4.81 \\
5.00\end{array}$ & $\begin{array}{l}-6.01 \\
-4.60 \\
-5.12 \\
-5.01\end{array}$ & $\begin{array}{l}199 \\
234 \\
197 \\
197\end{array}$ & $\begin{array}{l}188 \\
236 \\
195 \\
195\end{array}$ & $\begin{array}{l}13.8 \\
16.1 \\
14.4 \\
15.4\end{array}$ & \begin{tabular}{|l|}
14.5 \\
16.3 \\
10.9 \\
14.7
\end{tabular} & $\begin{array}{l}6.13 \\
3.98 \\
5.66 \\
6.25\end{array}$ & $\begin{array}{l}6.46 \\
4.79 \\
4.38 \\
5.89\end{array}$ \\
\hline
\end{tabular}

${ }^{1)}$ Plastic stress distribution method

${ }^{2)}$ Strain compatibility method 


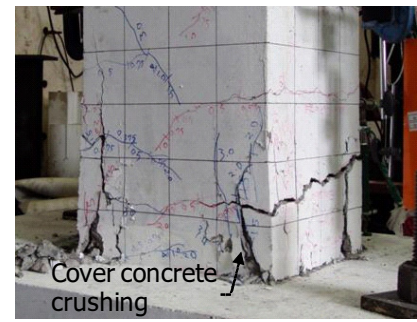

(a) $51: 4.0 \%$

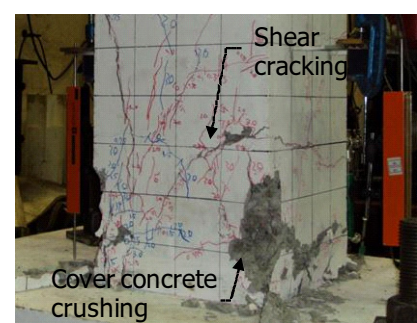

(e) S3: $3.0 \%$

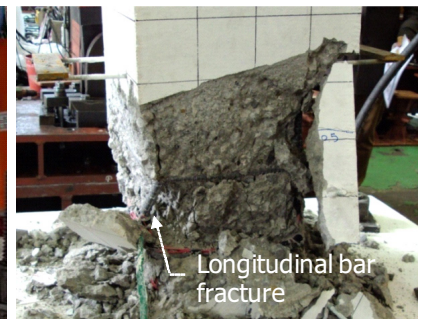

(b) $51: 7.0 \%$

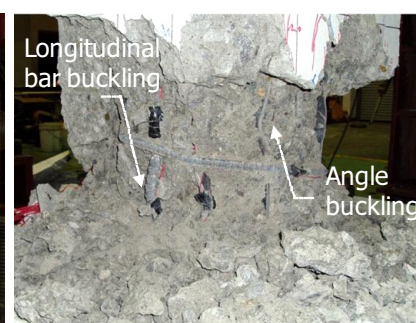

(f) S3: $6.0 \%$

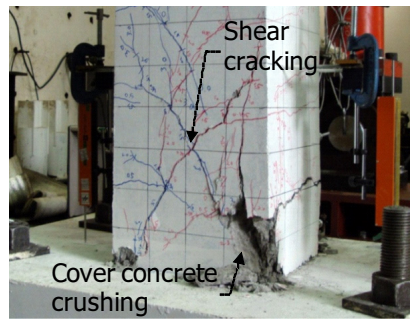

(c) S2: $3.0 \%$

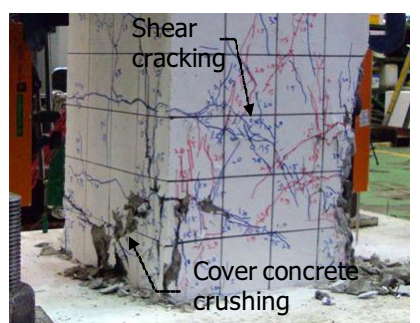

(g) $54: 3.0 \%$

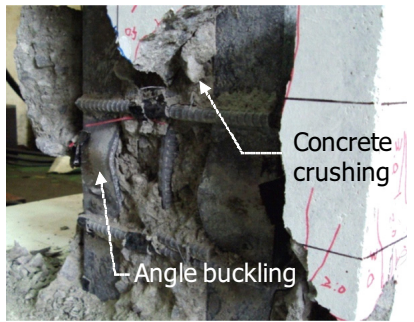

(d) S2: $5.0 \%$

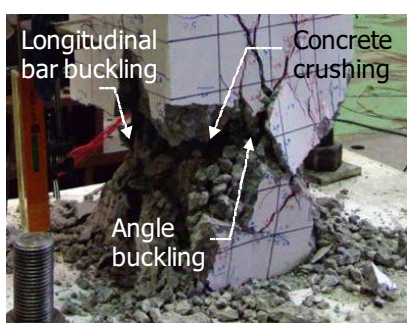

(h) S4: 6.0\%

Fig. 5 Crack patterns and failure aspects in plastic hinge regions

전단손상의 감소는 Fig. 4(c)에 보는 바와 같이 $\mathrm{S} 3$ 의 최대 강도가 S2 대비 약 $25 \%$ 감소하였기 때문이다. 또한 S3의 연속후프는 원형에 가까운 8각형으로 $\mathrm{S} 2$ 의 직사각형 용접후 프보다 콘크리트 횡구속 효과가 우수하고 ${ }^{[13]}$, 앵글의 모든 단 면이 연속후프로 횡보강된 콘크리트에 노출 없이 완전히 매 입되어 앵글의 좌굴이 효과적으로 억제된다(Fig. 6 참조). 그 결과 Fig. 4(c)에 나타낸 바와 같이 S3는 $5.0 \%$ 횡변위 비까지 매우 안정적이고 에너지소산능력이 우수한 내진성능 을 보였다. $5.0 \%$ 이후 피복 콘크리트 파괴로 인하여 앵글 및 주근이 외부로 노출되었지만, 연속후프로 횡구속된 내부 콘크리트는 거의 온전하게 휨-압축에 저항하였다. 종국적으로 $\mathrm{S} 3$ 는 $6.0 \%$ 변위비에서 앵글 및 주근의 좌굴과 그로 인한 횡보강된 내부 콘크리트의 압괴에 의하여 파괴되었다(Fig. 5(f) 참조).

Fig. 4(d)는 연속후프로 횡보강한 PSRC 합성기둥 실험 체 S4의 하중-변위비 응답을 나타낸다. S4는 앵글과 콘크리 트 사이에 별도의 부착 상세가 없음에도 불구하고 $\mathrm{S} 3$ 와 거의 동일한 주기거동을 보였다. $2.0 \%$ 횡변위비에서 휨 및 전단 균열(약 $\left.35^{\circ} \sim 55^{\circ}\right)$ 이 발생하였고, 기둥 하단부에서 휨-압축 에 의한 피복 콘크리트의 파괴가 시작되었다. Fig. $5(\mathrm{~g})$ 에 보는 바와 같이 $3.0 \%$ 의 횡변위비에서 기둥 하부의 콘크리트 피복이 완전히 파괴되었지만, Fig. 4(d)의 하중-변위 응답에 서는 뚜렷한 강도 및 강성저하가 나타나지 않았다. 이는 연속 후프에 의하여 내부 콘크리트가 효과적으로 횡구속되었고, Fig. 6에 나타낸 바와 같이 콘크리트 피복파괴 이후에도 앵 글의 전단면이 콘크리트로 매입되어 조기 국부좌굴이 억제되 었기 때문이다. 종국적으로 $\mathrm{S} 4$ 는 $6.0 \%$ 횡변위비에서 앵글

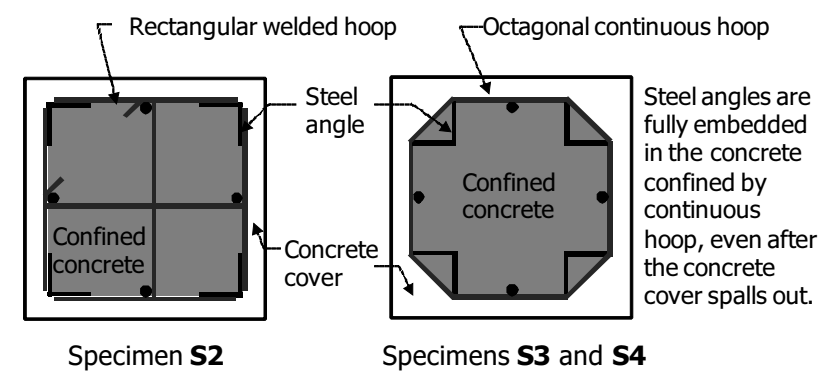

Fig. 6 Comparison of Confinements by rectangular welded hoop and octagonal continuous hoop

및 주근의 좌굴과 횡보강된 내부 콘크리트의 압괴로 인하여 파괴되었다(Fig. 5(h) 참조).

\section{2 강재 및 철근 변형률}

Fig. 7은 기둥 실험체의 $\mathrm{H}$ 형강 및 앵글의 변형률 계측결 과를 보여준다. 세로축 및 가로축은 각각 강재의 축방향 인장 변형률과 기둥의 횡변위비를 나타낸다. S1의 경우 게이지를 $\mathrm{H}$ 형강의 플랜지 표면에 부착하였고, $\mathrm{S} 2 \sim \mathrm{S} 4$ 의 경우 기둥 단면 중심으로부터 가장 바깥쪽의 앵글 표면에 부착하였다. $\mathrm{H}$ 형강 및 앵글의 축방향 변형률은 기초면(또는 위험단면)과 기초면으로부터 $200 \mathrm{~mm}$ 높이에서 계측하였다.

단면 중앙에 $\mathrm{H}$ 형강을 매입한 기존 $\mathrm{SRC}$ 합성기둥 실험체 $\mathrm{S} 1$ 의 경우(Fig. 7(a) 및 (b) 참조), $3.0 \%$ 의 횡변위비까지 기초면 및 기초면으로부터 $200 \mathrm{~mm}$ 높이에서 거의 동일한 변 형률을 보였다. 이후 기초면에서 계측한 $\mathrm{H}$ 형강 플랜지의 축 변형률이 갑자기 감소하였는데(Fig. 7(a) 참조), 이는 플랜 

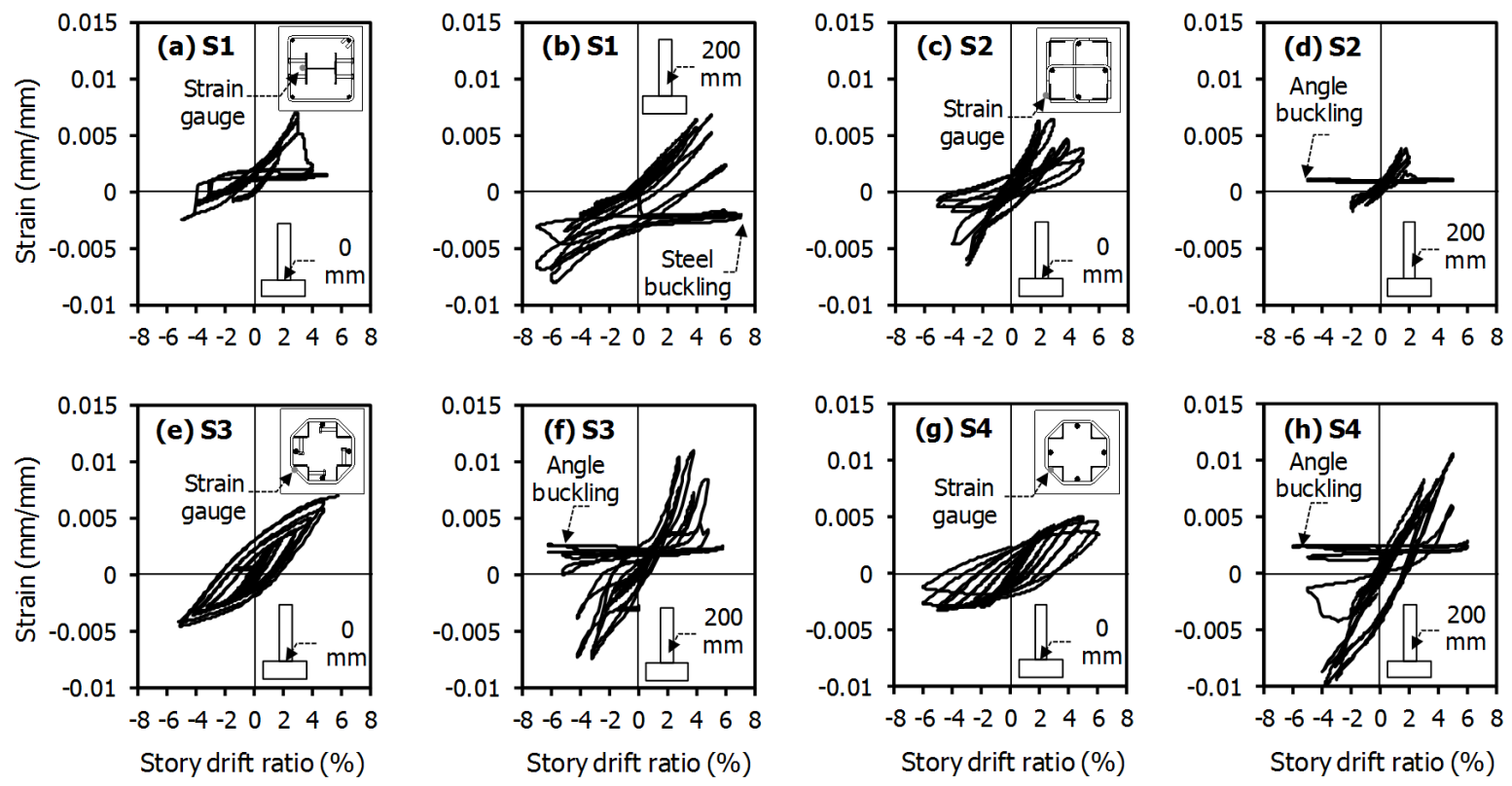

Fig. 7 Strains of steel sections encased by concrete

지에 국부 좌굴이 발생하였기 때문으로 판단된다. 기초면으로 부터 $200 \mathrm{~mm}$ 위치에서 계측한 강재의 변형률 또한 $5.0 \%$ 횡변위비에서 플랜지 좌굴로 인하여 급격히 저하되며 주기거 동 동안 압축변형률을 보였다.

Fig. $7(\mathrm{c})$ 와 $(\mathrm{d})$ 는 앵글과 용접후프를 사용한 PSRC 합 성기둥 실험체 $\mathrm{S} 2$ 의 앵글 변형률을 보여준다. 앵글 변형률은 $3.0 \%$ 까지 기둥 횡변위비에 비례하여 증가하였지만, 이후 앵 글에 조기 국부좌굴이 발생되어 변형률이 감소하였다. 기초면 으로부터 $200 \mathrm{~mm}$ 높이에서 계측한 앵글 변형률이 기초면보 다 상대적으로 작았는데, 이는 직각방향 철근이 앵글에 용접 되어 국부적으로 앵글의 강성이 증가된 부분에서 앵글 변형 률이 계측되었기 때문으로 판단된다(Fig. 7(d) 참조).

Fig. $7(\mathrm{e}) \sim(\mathrm{h})$ 는 앵글을 연속후프로 횡보강한 PSRC 합 성기둥 실험체 S3과 $\mathrm{S} 4$ 의 앵글 변형률을 보여준다. 두 실험 체 모두 앵글 변형률이 기둥 횡변위비에 비례하여 증가하였 고, 주기거동 동안 항복변형률보다 큰 인장 및 압축의 소성변 형률을 보였다. 기초면보다는 기초면으로부터 $200 \mathrm{~mm}$ 위치 에서 계측한 앵글의 변형률이 상대적으로 더 컸다. 특히 앵글 의 국부좌굴이 시작된 $4.0 \%$ 횡변위비에서 기초면으로부터 $200 \mathrm{~mm}$ 에서 계측된 S3과 $\mathrm{S} 4$ 의 앵글 변형률이 갑자기 감소 하였고, 이후 기둥 횡변위비에 관계없이 거의 일정한 인장변 형률을 보였다. 이는 S3 및 S4의 앵글에서 발생된 국부좌굴 은 대부분 기초면으로부터 $200 \mathrm{~mm}$ 떨어진 위치에 집중되었 음을 가리킨다. 이와 달리, Fig. 7(e) 및 $(\mathrm{g})$ 에 나타낸 바와 같이 기초면의 앵글 변형률은 매우 안정적인 이력곡선을 보 였다. 특히, 기초면에서 계측한 Fig. 7(a) 및 (c)에 비해서
도 매우 안정적인 이력곡선을 보였는데, 이러한 차이는 실험 체 $\mathrm{S} 1$ 및 $\mathrm{S} 2$ 가 강재 좌굴과 스터드와 용접후프의 용접에 의 한 강재의 열경화에 영향을 받았기 때문으로 판단된다.

실험체 $\mathrm{S} 4$ 에서는 앵글과 횡철근을 가용접하고 추가적인 기계적 부착을 사용하지 않으므로 국부적으로 부착미끄러짐 이 발생하여 기초면에서 계측된 앵글의 축방향 변형률은 S3 의 변형률보다 다소 감소하였지만, 전반적인 이력거동에서 유 의미한 차이는 관찰되지 않았다(Fig. $7(\mathrm{e}) \sim(\mathrm{h})$ 및 Fig. $4(\mathrm{c}) \sim(\mathrm{d})$ 참조). 이러한 결과는 앵글에 스터드를 사용하지 않더라도, Fig. 6과 같이 앵글이 연속후프로 횡구속된 콘크 리트 내부에 완전히 매입되고 앵글에 용접된 상 - 하 타이강 판의 전단저항이 작용하는 경우 앵글-콘크리트 사이의 부착 강도가 확보될 수 있다는 사실을 가리킨다. 따라서 Fig. 2(d) 에 나타낸 $\mathrm{S} 4$ 는 시공성 및 경제성이 우수한 PSRC 합성기둥 대안 상세로 활용될 수 있을 것으로 판단된다.

Fig. 8은 직각방향으로 배치된 타이 철근의 변형률 계측 결과를 보여준다. 타이 철근의 변형률은 기초면으로부터 50 $\mathrm{mm}$ 및 $200 \mathrm{~mm}$ 위치에서 계측하였다. 그림의 가로축과 세 로축은 각각 기둥의 횡변위비와 타이 철근의 변형률을 나타 낸다. 기존 $\mathrm{SRC}$ 합성기둥 실험체 $\mathrm{S} 1$ 의 경우, $\mathrm{H}$ 형강 웨브가 전단에 저항하므로 타이 철근의 인장변형률이 가장 작았다. 반면, PSRC 합성기둥 실험체 $\mathrm{S} 2$ 의 경우, 타이 철근이 내부 콘크리트의 횡구속뿐만 아니라 전단에 대해서도 저항하여야 하므로 기초면으로부터 $50 \mathrm{~mm}$ 높이에서 계측한 타이 철근의 변형률이 크게 증가하였다(Fig. 8(c) 참조). 특히, 콘크리트 피복파괴가 발생된 횡변위비 $3.0 \%$ 이후에 타이 철근의 인장 

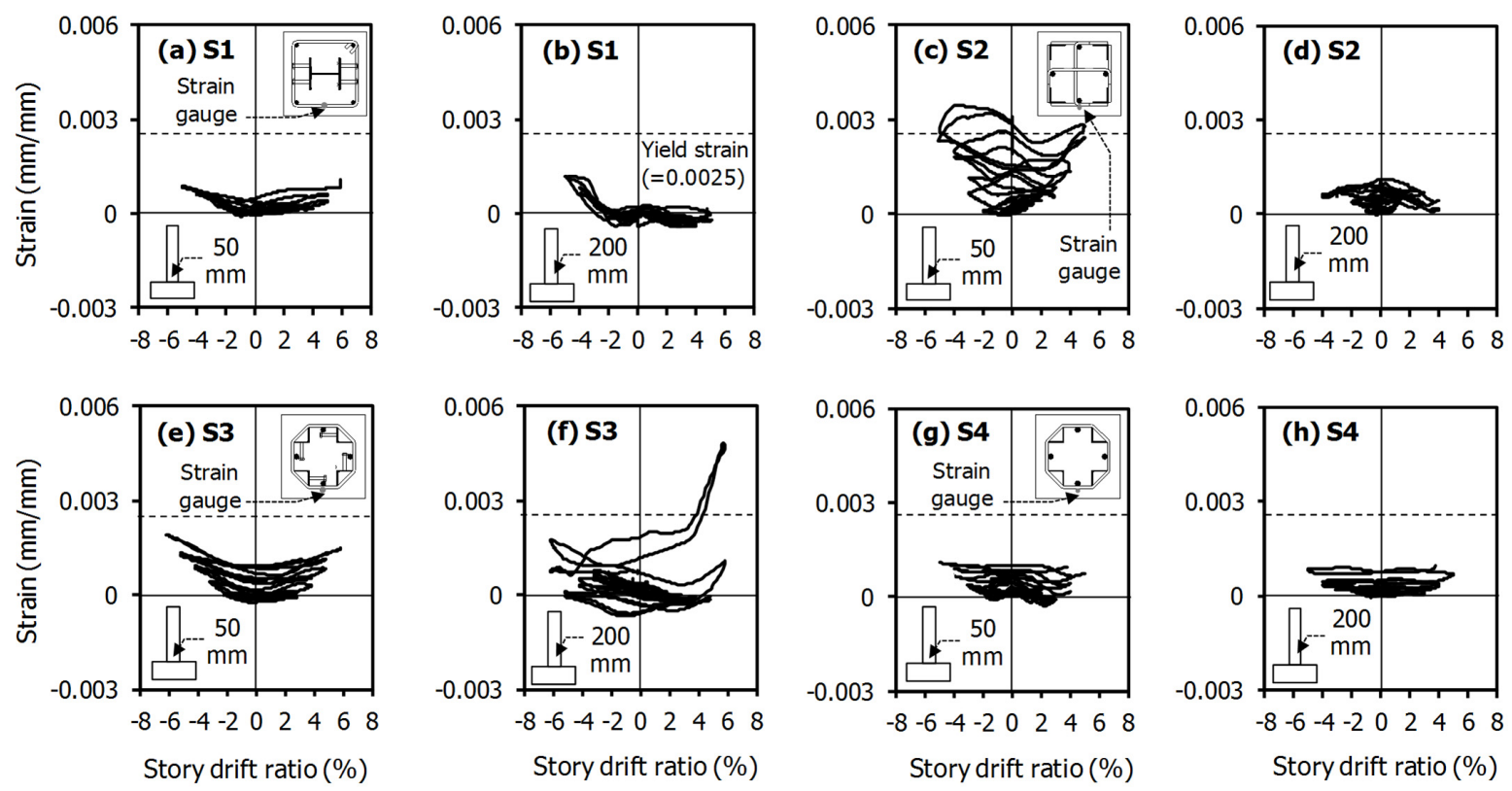

Fig. 8 Strains of transverse ties

변형률이 급격히 증가하여 항복 변형률 $(=0.0025)$ 이상을 발휘하였는데, 이는 피복 콘크리트 파괴로 인하여 감소된 콘 크리트의 전단저항 만큼 직각방향의 타이 철근의 전단저항이 증가하였고 앵글 좌굴방지를 위한 저항이 추가되었기 때문으 로 판단된다.

연속후프를 적용한 PSRC 합성기둥 실험체 $\mathrm{S} 3$ 와 $\mathrm{S} 4$ 의 경 우, $\mathrm{S} 2$ 와 동일하게 직각방향의 타이 철근(또는 연속후프)이 내부 콘크리트를 횡구속하고 동시에 기둥의 전단력을 전달하 여야 한다. Fig. $8(\mathrm{e}) \sim(\mathrm{h})$ 에 보는 바와 같이, 동일한 직경 및 간격의 타이 철근을 사용하였음에도 불구하고, $\mathrm{S} 3$ 와 $\mathrm{S} 4$ 의 연속후프는 주기거동 동안 $\mathrm{S} 2$ 의 타이 철근보다 변형률이 작았다. 이는 $\mathrm{S} 3$ 와 $\mathrm{S} 4$ 의 최대전단력이 $\mathrm{S} 2$ 보다 $25 \%$ 작았고 (Fig. 4 및 Table 2 참조), 콘크리트 피복 파괴 이후에도 8 각형의 연속후프로 횡구속된 내부 콘크리트가 전단에 효과적 으로 저항하였기 때문으로 판단된다.

\section{4. 내진성능 분석}

\section{1 강도 및 항복강성}

축력이 작용하는 합성기둥 실험체의 휨강도를 현행 $\mathrm{KBC}$ $2009^{[10]}$ 에 제시된 단면설계방법을 사용하여 평가하였다. 기 둥 실험체의 공칭강도 $P_{n}$ 는 압축력 $N=800 \mathrm{kN} \quad(=0.224$ $\left.A_{q} f_{c k}\right)$ 를 고려하여 다음과 같이 평가하였다. 실제 콘크리트 의 압축강도 $f_{c k}$, 강재 항복강도 $F_{y}$, 철근 항복강도 $f_{y}$ 를
사용한 단면해석을 통하여 기둥 단면의 공칭 휨모멘트강도 $M_{n}$ 를 계산하고, 이를 기둥 전단경간 $H_{e}(=1,500 \mathrm{~mm})$ 로 나누어 기둥의 공칭강도 $P_{n 0}\left(=M_{n} / H_{e}\right)$ 을 구하였다. 여기 서, 기둥 단면에 대한 단면해석은 $\mathrm{KBC} 2009$ 의 0709장에 따라 강재, 철근, 콘크리트 등 재료의 소성응력분포를 가정하 는 소성응력분포법(Method 1)과 단면의 선형변형률 분포에 기반한 재료의 비선형 응력을 사용하는 변형률적합법(Method 2)으로 계산하였다. 강재, 철근, 콘크리트의 응력-변형률 관 계 및 비선형 단면해석 방법은 참고문헌 10 과 11 에 상세하 게 나타나 있다.

압축력이 작용하는 기둥 실험체는 횡변위비 $\delta$ 가 증가할수 록 압축력 $N$ 에 의한 이차효과로 인하여 하중재하능력이 감 소한다. 따라서 기둥 실험체의 공칭강도 $P_{n}$ 은 이차효과를 고려하여 다음과 같이 보정하였다.

$$
P_{n}=P_{n 0}-N \delta
$$

여기서, $P_{n 0}$ 는 이차효과가 고려되지 않은 공칭강도이다.

식 (1)을 사용하여 횡변위비에 따라 감소하는 기둥 실험체 의 하중재하능력을 Fig. $4(\mathrm{a}) \sim(\mathrm{d})$ 에 점선으로 나타냈다. 그 림에 나타낸 $P_{n}$ 은 소성응력분포법을 사용하여 계산한 하중 재하능력으로, 실험 결과와 비교적 잘 일치하였다. 특히, 횡 변위비가 증가함에 따라 이차효과로 인하여 감소되는 강도 저하를 매우 정확하게 예측하였다. Table 2 는 소성응력분포 법(Method 1)과 정밀 비선형 단면해석(변형률적합법, Method 
2)으로 구한 각 실험체의 공칭 하중재하능력을 보여주는데 $\mathrm{H}$ 형강 플랜지가 중립축 근처에 위치하는 $\mathrm{S} 1$ 을 제외하고는 두 방법에 의한 공칭강도가 유사하였다. 이는 $\mathrm{KBC} 2009^{[10]}$ 의 합성 구조설계기준을 그대로 사용하여 $\mathrm{S} 2, \mathrm{~S} 3, \mathrm{~S} 4$ 와 같은 $\mathrm{PSRC}$ 기둥의 휨압축 설계를 수행할 수 있음을 잘 보여준다.

비록 S1 S4 모두 동일한 강재비 $(=2.2 \%)$ 를 사용하였음 에도 불구하고, 강재의 종류와 배열 방향에 따라 각 기둥 실 험체의 하중재하능력이 달랐다. 단면의 중심에 $\mathrm{H}$ 형강을 매입 한 기존 $\mathrm{SRC}$ 합성기둥 실험체 $\mathrm{S} 1$ 에 비하여, 4 개의 앵글을 단면의 네 모서리에 배치한 S2 실험체는 최대강도 $P_{u}$ 가 $20 \%$ 증가하였다(Table 2 참조). 그러나 연속후프를 사용하 여 직각방향 타이철근의 시공성을 개선하고 용접량을 줄인 $\mathrm{S} 3$ 과 $\mathrm{S} 4$ 의 경우, $\mathrm{S} 2$ 와 동일하게 앵글을 단면의 네 모서리에 배치하였음에도 불구하고 최대강도 $P_{u}$ 가 크게 감소하였다. 이는 앵글의 배치 방향이 바뀌어 앵글 플랜지가 기둥 단면의 중심에 가까워져 단면의 휨저항 성능이 줄었기 때문이다. S4 의 경우 PSRC 합성기둥의 시공성 및 용접 물량을 최소화하 기 위하여 앵글과 콘크리트 사이에 별도의 부착 상세를 적용 하지 않았음에도 불구하고, $\phi 16$ 스터드를 사용한 S3과 거 의 동일한 최대강도를 보였다.

Table 2는 각 실험체의 항복강성 $k_{y}$ 을 보여준다. Fig. 4(f)에 나타낸 바와 같이, 항복강성 $k_{y}$ 는 최대강도 $P_{u}$ 를 항복변위 $\Delta_{y}\left(=\delta_{y} H_{e}\right)$ 로 나누어 계산하였다. 기존 $\mathrm{SRC}$ 합성기둥 실험체 $\mathrm{S} 1$ 의 경우, $\mathrm{H}$ 형강이 단면 중심에 배치됨에 따라 초기 휨균열 발생이후 휨강성이 감소하여 항복강성이 $13.8 \sim 14.5 \mathrm{kN} / \mathrm{mm}$ 로 가장 작았다. 반면, $\mathrm{PSRC}$ 합성기둥 실험체 $\mathrm{S} 2$ 의 경우, 단면 네 모서리에 앵글을 배치함에 따라 단면의 휨저항성능이 증가하여 항복강성이 $16.1 \sim 16.3 \mathrm{kN} / \mathrm{mm}$ 로 가장 큰 값을 보였다. 앵글의 배치 방향을 변경한 PSRC 합성기둥 실험체 S3과 $\mathrm{S} 4$ 는 항복강성이 $14.4 \sim 15.4 \mathrm{kN} / \mathrm{mm}$ 로 S1과 거의 동일한 값을 보였다. (S3의 경우 부방향의 항 복강성이 $10.9 \mathrm{kN} / \mathrm{mm}$ 로 매우 작았는데, 이는 기둥 실험체 의 수직도 문제로 인하여 횡변위비 $1.0 \%$ 까지 발생한 비대칭 가력에 의한 결과이다.) 특히, 앵글과 콘크리트 사이의 부착 상세를 단순화시킨 $\mathrm{S} 4$ 의 경우, 스터드를 사용한 $\mathrm{S} 3$ 과 동등한 항복강성을 보였다. 이러한 각 실험체별 항복강성은 Table 2 에 정리된 강재 종류 및 배치에 따른 최대강도 변화와 일관 된 경향을 보였다.

\section{2 변형능력 및 에너지소산능력}

Table 2에 나타낸 바와 같이, 모든 SRC 및 PSRC 합성 기둥 실험체는 비교적 높은 압축력 $N=800 \mathrm{kN}(=0.224$
$\left.A_{g} f_{c k}\right)$ 이 작용되었음에도 불구하고 $3.98 \%$ 이상의 우수한 변형능력 $\delta_{u}$ 를 발휘하였다. 최대변위비를 항복변위비로 나누 어 계산한 변위연성도 $\mu\left(=\delta_{u} / \delta_{y}\right)$ 또한 모든 실험체는 3.98 이상으로 우수한 연성능력을 보였다. 그러나 합성기둥 실험체 의 변형능력은 강재 단면의 배치와 횡보강 상세에 따라 큰 차이를 보였다.

단면의 중심에 $\mathrm{H}$ 형강을 매입하고 주변 콘크리트를 4D19 주근과 D13@150의 직사각형 후프로 횡보강한 기존 SRC 합성기둥 $\mathrm{S} 1$ 은 $6.01 \%$ 의 가장 우수한 변형능력을 보였다. 반면, 앵글을 기둥 단면의 네 모서리에 배치하고 용접후프 철 근으로 횡보강한 $\mathrm{S} 2$ 는 변형능력이 $3.98 \%$ 로 $\mathrm{S} 1$ 보다 약 $34 \%$ 급격히 감소하였는데 그 이유는 다음과 같다. 선행연구 ${ }^{[7]}$ 에 의하면 S2는 앵글 표면에 용접된 후프 철근과 피복 콘 크리트 사이의 지압작용으로 앵글-콘크리트의 부착강도가 확 보되므로, $3.0 \sim 4.0 \%$ 의 횡변위비에서 기둥 하부 소성힌지에 서 피복 콘크리트가 파괴 된 이후에는 부착강도의 손실이 급 격히 커진다. 또한 피복 콘크리트 파괴 이후에는 외부로 직접 노출된 앵글의 국부좌굴과 함께 횡보강된 콘크리트의 압괴가 거의 동시에 발생한 결과, $\mathrm{S} 2$ 의 하중재하능력이 급격히 저하 되었다.

이와 달리, 앵글의 배치 방향을 바꾸고 연속후프를 사용하 여 시공성을 개선시킨 PSRC 합성기둥 실험체 $\mathrm{S} 3$ 와 $\mathrm{S} 4$ 의 경우, Fig. 6에 나타낸 바와 같이 피복 콘크리트의 파괴 이 후에도 앵글이 횡보강된 콘크리트 내부에 매입되어 있으므로 앵글의 좌굴이 상당히 지연되었다. 또한 앵글 플랜지가 기둥 단면 중심에 가까이 배치됨에 따라 하중재하능력이 감소한 대신에 동일 곡률에서 $\mathrm{S} 2$ 에 비해 앵글 플랜지의 변형률이 감 소하게 되며, 이는 앵글의 좌굴을 지연시키고 부착강도 손실 을 감소시켰다. 그 결과, $\mathrm{S} 3$ 와 $\mathrm{S} 4$ 는 용접후프를 사용한 $\mathrm{S} 2$ 에 비하여 변형능력이 크게 향상되었다.

Fig. 9는 횡변위비에 따라 증가하는 각 실험체의 에너지소 산량 변화를 보여준다. 에너지소산량은 Fig. 4 의 하중-변위 관계를 바탕으로 동일한 정 - 부 방향 횡변위비에서 반복되는 두 번째 재하사이클의 주기곡선의 면적으로 계산하였다. 약 $4.0 \%$ 변위비까지는 기둥 단면의 네 모서리에 앵글을 배치하 여 단면의 휨저항성을 높인 S2가 가장 많은 이력 에너지를 소산하였고, 강재를 기둥 단면의 중심에 집중시킨 $\mathrm{S} 1, \mathrm{~S} 3$, $\mathrm{S} 4$ 는 상대적으로 작은 에너지소산량을 보였다. $4.0 \%$ 이후 강도저하가 발생된 $\mathrm{S} 2$ 는 이후 에너지소산량이 거의 증가하지 않았지만, 보다 우수한 변형능력을 보인 S1, S3, S4의 경우 $5.0 \%$ 이후에도 에너지소산량이 횡변위비에 비례하여 증가하 는 경향을 보였으며, 최종적으로 $\mathrm{S} 1$ 이 가장 큰 에너지 소산 량을 보였다. 


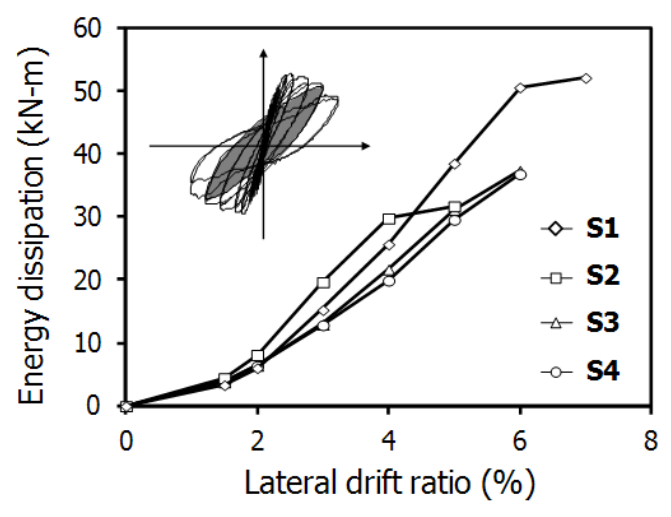

Fig. 9 Energy dissipation per a cycle

\section{3 부착성능}

이전연구에 의하면, 앵글-콘크리트 부착강도 $T_{b n 1}$ 는 앵글 표면에 용접된 횡방향 철근과 콘크리트 사이의 지압작용으로 이루어진다(Fig. 10 참조 $)^{[7]}$. 본 연구에서는 실험체 $\mathrm{S} 3$ 과 같이 스터드를 적용하는 경우 부착강도 $T_{b n 2}$ 를 추가하였다.

$$
\begin{aligned}
& T_{b n 1}=2\left[0.85 f_{c k}\left(2 d_{b h} l_{w h}\right)\left(\frac{l_{s}}{s}\right)\right] \\
& T_{b n 2}=0.5 A_{s c} \sqrt{f_{c k} E_{c}} n_{s}
\end{aligned}
$$

여기서, $d_{b h}=$ 횡방향 철근의 직경, $l_{w h}=$ 앵글에 용접된 횡방 향 철근의 용접 길이, $l_{s}=$ 전단경간 길이, $s=$ 횡방향 철근의 간격, $A_{s c}=$ 스터드 단면적, $E_{c}=$ 콘크리트 탄성계수, $n_{s}=$ 전단경간 사의의 스터드 개수이다. 부착미끄러짐을 방지하기
Table 3. Evaluation of Bond Strength

\begin{tabular}{c|c|c|c}
\hline \multirow{2}{*}{ Specimen } & \multicolumn{3}{|c}{ Bond capacity } \\
\cline { 2 - 4 } & $T_{b n 1}{ }^{1)}(\mathrm{kN})$ & $T_{b n 2}{ }^{1)}(\mathrm{kN})$ & $\left(T_{b n 1}+T_{b n 2}\right) / T_{b u}$ \\
\hline S2 & 721 & - & 1.35 \\
S3 & 62 & 513 & 1.07 \\
S4 & 62 & - & 0.12 \\
\hline
\end{tabular}

${ }^{1)}$ Capacity based on material test

위해서 부착강도 $T_{b n 1}+T_{b n 2}$ 은 앵글의 인장항복 이후 변형 경화거동에 의한 응력 증가를 고려하여 전단면적 항복에 의 한 축방향 인장력의 1.3 배 $\left(=1.3 A_{s a} F_{y}, A_{s a}=\right.$ 하나의 앵글 단면적)보다 커야 한다 ${ }^{[7]}$.

앵글 1 개의 전단면 인장(또는 압축)항복에 필요한 소요부 착강도 $T_{b u}=536 \mathrm{kN}\left(=1.3 A_{s a} F_{y}, A_{s a}=\right.$ 앵글의 단면적 $864 \mathrm{~mm}^{2}, F_{y}=$ 앵글의 항복강도 $477 \mathrm{MPa}$ )이다. 공칭 지압 강도 $T_{b n}$ 계산을 위하여, 횡방향 철근의 직경과 용접길이, 부착전단 구간은 각각 $d_{b h}=13 \mathrm{~mm}$ 및 $l_{w h}=70 \mathrm{~mm}, l_{s}=$ $1,500 \mathrm{~mm}$ 를 사용하였고 콘크리트 압축강도는 $f_{c k}=23.3 \mathrm{MPa}$ 를 사용하였다(식 (2) 및 Fig. 10 참조). 연속후프근을 적용 한 실험체 $\mathrm{S} 3$ 과 $\mathrm{S} 4$ 의 경우 용접길이 $l_{w h}$ 는 앵글 모서리에 서만 용접이 되기 때문에 안전측으로 앵글 두께인 $6 \mathrm{~mm}$ 만 고려하였다. Table 3에 나타난 바와 같이 실험체 S2, S3, $\mathrm{S} 4$ 의 공칭 부착강도 $T_{b n 1}=721 \mathrm{kN}, 62 \mathrm{kN}, 62 \mathrm{kN}$ 이며, $\mathrm{S} 3$ 의 $T_{b n 2}=513 \mathrm{kN}$ 이다.

실험체 $\mathrm{S} 2$ 는 부착강도가 충분히 크기 때문에 부착 미끄러 짐이 발생하지 않았으며, 실험체 $\mathrm{S} 3$ 의 경우 주로 스터드에 의해 부착에 저항하였다. 반면에 실험체 $\mathrm{S} 4$ 는 연속후프근 지 압에 의한 부착강도가 부족함에 따라 국부적으로 앵글의 부

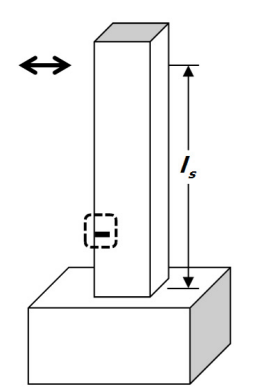

Lateral cyclic test of PSRC column
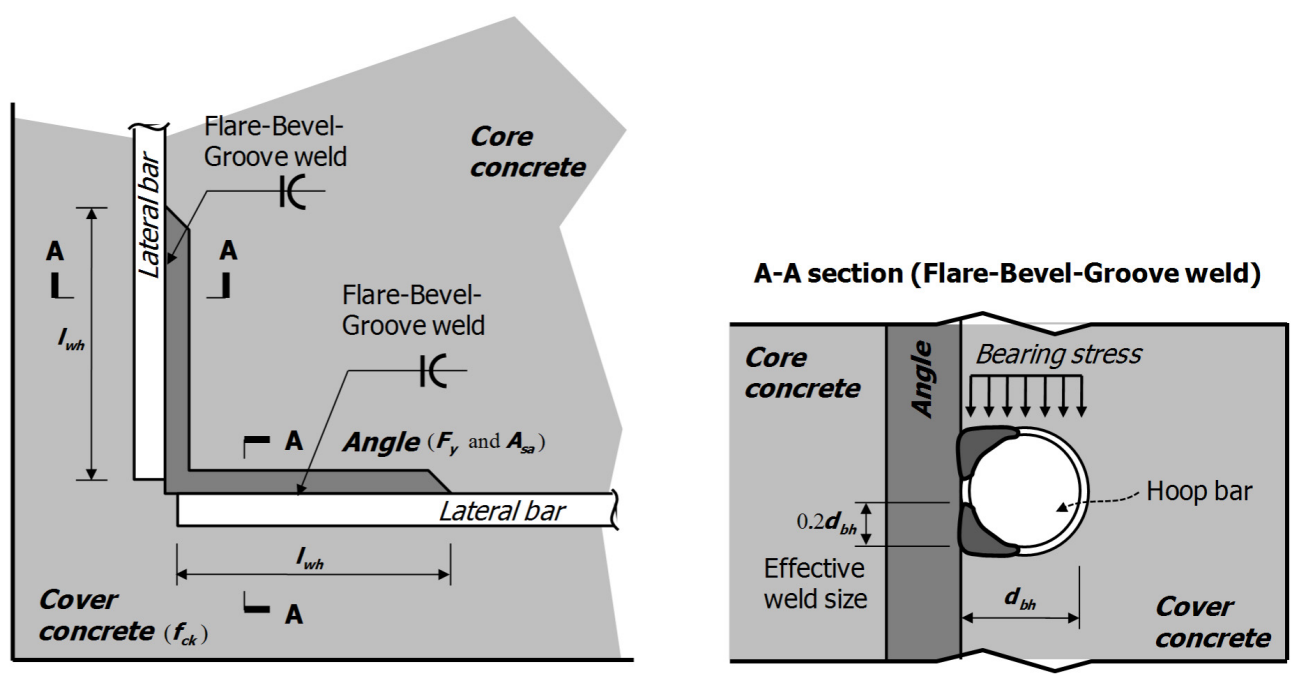

Fig. 10 Bond strength between angle and concrete of PSRC column 
착미끄러짐이 발생하였지만, 휨에 의해 단면의 좌·우 앵글에 각각 작용하는 인장력 및 압축력을 상-하 타이강판의 수평 전단 저항력 $\left(=0.6 A_{s s} F_{y s}=1,320 \mathrm{kN}, A_{s s}=\right.$ 타이강판 단 면적 $5,000 \mathrm{~mm}^{2}, F_{y s}=$ 전단강판의 항복강도 $440 \mathrm{MPa}$ )에 의해서 상쇄함에 따라 전체적인 거동은 $\mathrm{S} 3$ 과 동일하였다.

\section{4 설계 고려사항}

본 연구에서는 기둥 단면의 네 모서리에 앵글을 배치하여 단면의 휨저항성능을 극대화한 선행연구의 기존 PSRC 합성 기둥 상세(실험체 S2)와 부착성능 및 시공성을 개선한 새로 운 PSRC 합성기둥 상세(실험체 S3 및 S4)에 대하여 내진 성능을 평가하였다. 본 장의 분석 결과를 바탕으로 다음과 같 은 PSRC 합성기둥의 구조설계 권고사항을 제안하였다.

(1) 기둥 단면의 휨저항성능이 최적화되도록 앵글을 배치하 고 용접후프를 사용하여 횡보강한 $\mathrm{S} 2$ 의 경우, $\mathrm{H}$ 형강을 사용하는 기존 SRC 합성기둥 실험체 S1보다 하중재하 능력이 $20 \%$ 이상 증가하였지만 소성힌지에서 피복 콘 크리트 파괴 후 앵글의 국부좌굴 및 전단균열로 인하여 변형능력 $(=3.98 \%)$ 이 감소하였다. 따라서 $\mathrm{S} 2$ 와 같은 $\mathrm{PSRC}$ 합성기둥 단면 상세는 휨모멘트가 지배적인 비내 진구조 또는 연성요구량이 크지 않은 중간모멘트골조 이 하의 내진구조에 적용하는 것이 바람직하며, 보다 큰 연성 능력을 위해서는 횡보강근을 추가로 배치할 필요가 있다.

(2) 앵글 플랜지를 단면의 중심 방향으로 배치한 S3 및 S4 는 S2보다 최대강도가 약 $25 \%$ 감소하였다. 하지만 연 속후프를 사용하여 횡보강한 결과, 피복 콘크리트 파괴 이후에도 앵글이 횡보강된 콘크리트 내부에 완전히 매입 되어 앵글의 국부좌굴이 지연되므로 변형능력이 $\mathrm{S} 2$ 보다 $20 \%$ 이상 크게 향상되어 안정적인 주기거동을 보였다. 또한 Fig. 2(d)에 나타낸 바와 같이 앵글과 콘크리트 사이의 부착 상세를 단순화하여 PSRC 합성기둥의 용접 물량을 줄이고 시공성을 더욱 높일 수 있다. S4와 같은 PSRC 합성기둥의 대안 상세는 압축력이 지배적인 비내 진구조 또는 연성요구량이 큰 특수모멘트골조에서 경제 적이고 시공성이 높은 합성기둥 상세로 적용하는 것이 좋다.

\section{5. 결 론}

선행 연구 ${ }^{[6],[7]}$ 에 의하면, 기둥 단면의 휨저항성능을 높이 고 선조립을 통한 시공성 향상을 위하여 개발된 PSRC 합성
기둥은 피복 콘크리트 파괴 이후 앵글-콘크리트의 부착 파괴 와 앵글 국부좌굴이 조기에 발생할 수 있다. 본 연구에서는 단면의 휨저항 성능과 시공성을 각각 극대화한 PSRC 합성 기둥 상세를 제안하고, 주기재하 실험을 통하여 하중재하능 력, 변형능력, 파괴특성, 에너지 소산능력 등 내진성능을 검 증하였다. 본 연구의 주요한 결과는 다음과 같다.

(1) $\mathrm{H}$ 형강을 사용하는 기존 $\mathrm{SRC}$ 합성기둥과 앵글을 사용하 는 PSRC 합성기둥 모두 KBC 2009의 합성구조 설계기 준의 제시된 공칭강도를 상회하는 하중재하능력을 발휘하 였고, $0.22 f_{c k}$ 의 상당한 압축응력이 작용함에도 불구하 고 약 $4.0 \%$ 이상의 우수한 변형능력을 보였다. SRC 합 성기둥은 피복 콘크리트 파괴 이후 주철근의 좌굴과 저주 파 피로 파단에 의하여 최종 파괴되었고, PSRC 합성기둥 은 피복 콘크리트 파괴 이후 앵글의 국부좌굴과 심부 콘크 리트의 압축파괴로 인하여 파괴되었다.

(2) 앵글 표면에 용접된 후프철근과 피복 콘크리트 사이의 지 압작용에 의하여 앵글-콘크리트의 부착강도가 확보되는 기존 PSRC 합성기둥 실험체 S2의 경우, $3.0 \sim 4.0 \%$ 의 횡변위비에서 피복 콘크리트 파괴가 발생된 이후 앵글의 국부좌굴과 함께 하중재하능력이 급격히 저하되었다. 반 면 앵글이 연속후프로 횡보강된 콘크리트 내부에 완전히 매입된 PSRC 합성기둥 실험체 $\mathrm{S} 3$ 과 $\mathrm{S} 4$ 의 경우, 피복 콘크리프 파괴 이후에도 앵글-콘크리트 부착파괴와 앵글 국부좌굴이 지연되어 우수한 변형능력을 보였다.

(3) PSRC 합성기둥 실험체는 앵글의 배치 방향과 횡보강 상 세에 따라 명확한 거동의 차이를 보였다. 앵글 플랜지를 최대한 단면의 외곽으로 배치하고 용접후프근으로 횡보강 한 $\mathrm{S} 2$ 의 경우, 동일한 강재비의 $\mathrm{SRC}$ 합성기둥 실험체 $\mathrm{S} 1$ 보다 하중재하능력이 $20 \%$ 이상 증가하였지만 변형능 력은 $30 \%$ 이상 감소하였다. 반면 앵글 플랜지를 단면 중 심에 가깝게 배치하고 연속후프를 사용하여 횡보강한 S3 과 $\mathrm{S} 4$ 의 경우, $\mathrm{S} 2$ 보다 하중재하능력이 약 $25 \%$ 감소하였 지만 변형능력은 $20 \%$ 이상 증가하였다.

\section{감사의 글}

본 연구는 국토해양부가 출연하고 한국건설교통기술평가원 에서 위탁 시행한 R\&D정책인프라사업(11기술표준화09-01) 에 의한 성능기반 강-콘크리트 합성구조 설계기준개발 및 중 소기업청에서 지원하는 2011년도 산학연협력 기업부설연구 소 지원사업(No.00045821)의 연구비 지원의 의해 수행되 었으며, 이에 감사드립니다. 


\section{참 고 문 헌(References)}

〔1] Morino, S. (1997) Recent Developments in Hybrid Structures in Japan-Research, Design and Construction Engineering Structures, Elsevier, Vol. 20, No. 4, pp.336-346.

[2] 김형근, 김명한, 조남규, 김상섭, 김상대(2009) $\mathrm{yLRC}$ 합성기둥의 압축강도에 관한 실험 연구, 한국강구조학회논 문집, 한국강구조학회, 제21권, 제 5 호, pp.545-552.

Kim, H.G., Kim, M.H., Cho, N.G., Kim, S.S., and Kim, S.D. (2009) Experimental Study on the Compressive Strength of yLRC Composite Columns, Journal of Korean Society of Steel Construction, KSSC, Vol. 21, No. 5, pp.545-552 (in Korean).

〔3] 김보람, 강성덕, 김형근, 김명한, 김상대(2008) 강재 영 구거푸집을 사용한 $\mathrm{yLRC}$ 합성기둥의 내화성능 연구, 한 국강구조학회논문집, 한국강구조학회, 제 20 권, 제 3 호, pp. 365-375.

Kim, B.R., Kang, S.D., Kim, H.G., Kim, M.H., and Kim, S.D. (2008) A Study on the Fire Resistance of yLRC Composite Columns with Steel Sheet Forms and Angles, Journal of Korean Society of Steel Construction, KSSC, Vol. 20, No. 3, pp.365-375 (in Korean).

[4] Campione, G. (2010) R/C Columns Strengthend by Means of Steel Angles and Battens: Testing, Modeling and Design, Studies and Researches, Politecnico di Milano, Vol. 30, pp.42-72.

[5] Monturi, R., and Piluso, V. (2009) Reinforced Concrete Columns Strengthened with Angles and Battens Subjected to Eccentric Load, Engineering Structures, Elsevier, Vol. 31, No. 2, pp.539-550.

[6] 황현종, 엄태성, 박홍근, 이창남, 김형섭(2012) 고강도 앵글을 적용한 선조립 합성기둥의 압축 실험, 한국강구조 학회논문집, 한국강구조학회, 제24권, 제4호, pp.361-369.

Hwang, H.J., Eom, T.S., Park, H.G., Lee, C.N., and Kim, H.S. (2012) Compression Test for Prefabricated Composite Columns Using HighStrength Steel Angles, Journal of Korean Society of Steel Construction, KSSC, Vol. 24, No.4, pp.361-369 (in Korean).

[7] 엄태성, 황현종, 박홍근, 이창남, 김형섭(2012) 앵글과
철근을 조립한 PSRC 합성기둥의 휨 실험, 한국강구조학 회논문집, 한국강구조학회, 제24권, 제5호, pp.535-547. Eom, T.S., Hwang, H.J., Park, H.G., Lee, C.N., and Kim, H.S. (2012) Flexural Test for Prefabricated Composite Columns Using Steel Angle and Reinforcing Bar, Journal of Korean Society of Steel Construction, KSSC, Vol. 24, No.5, pp.535-547 (in Korean).

[8] 김창수, 박홍근, 이호준, 최인락(2013) $800 \mathrm{MPa}$ 강재 및 $100 \mathrm{MPa}$ 콘크리트를 적용한 ㄱ형 강재매입형 합성기 둥의 편십압축실험, 한국강구조학회논문집, 한국강구조학 회, 제25권, 제2호, pp.209-222.

Kim, C.S., Park, H.G., Lee, H.J., and Choi, I.R. (2013) Eccentric Axial Loading Test for ConcreteEncased L-section Columns using 800MPa Steel and $100 \mathrm{MPa}$ Concrete, Journal of Korean Society of Steel Construction, KSSC, Vol. 25, No. 2, pp.209-222 (in Korean).

[9] 엄태성, 최태우, 박홍근, 강수민, 진종민(2013) 연속후프 로 보강된 철근콘크리트 기둥의 내진실험, 대한건축학회논 문집, 대한건축학회, 제29권, 제2호, pp.29-37.

Eom, T.S., Choi, T.W., Park, H.G., Kang, S.M., and Jin, J.M. (2013) Seismic Tests on Reinforced Concrete Columns Confined with Continuous Hoops, Journal of Architectural Institute of Korea, AIK, Vol. 29, No. 2, pp.29-37 (in Korean).

〔10] 대한건축학회(2009) 건축구조설계기준 및 해설(KBC 2009) 기문당.

AIK (2009) Korea building code and commentary - structural, Architectural Institute of Korea (in Korean).

〔11] AISC 360 (2010) Specification for Structural Steel Buildings, American Institute of Steel Construction, USA.

〔12] Park, R. (1988) State-of-the-Art Report on Ductility Evaluation from Laboratory and Analytical Testing, Proceedings of 9th World Conference on Earthquake Engineering, Tokyo-Kyoto, Japan, Vol. 8, pp.605-616.

[13] Hoshikuma, J., Kawashima, K., Nagaya, K., and Taylor, A.W. (1997) Stress-Strain Model for Confined Reinforced Concrete in Bridge Piers, Journal of Structural Engineering, ASCE, Vol. 123, No. 5, pp.624-633. 
요 약 : PSRC 기둥은 앵글을 콘크리트에 매입시킨 기둥으로, 단면의 외곽 코너에 배치되는 앵글이 기둥의 휨-압축에 저항한다. 본 연 구에서는 KBC 2009에 따라 압축력을 가한 기둥에 대하여 횡방향 반복가력 실험을 통하여 내진성능을 검증하였다. 기둥 종류, 연속후프근 적용, 앵글에 스터드 적용을 실험 변수로 고려하였으며, $2 / 3$ 스케일을 갖는 한 개의 SRC 합성기둥과 세 개의 PSRC 합성기둥을 실험하였 다. 실험결과, $\mathrm{KBC} 2009$ 로 예측한 PSRC 합성기둥의 하중재하능력은 실험결과와 잘 일치하였으며, 변형능력과 에너지 소산에 있어서 우수 한 성능을 보여주었다. PSRC 합성기둥은 반복하중으로 인한 콘크리트 피복 탈락 이후, 앵글 및 주철근의 좌굴에 의해 실험체의 하중재하능 력이 감소하였다. 특히, 연속후프근을 적용한 PSRC 합성기둥은 앵글의 조기 국부좌굴이 억제되어 기존 PSRC 합성기둥에 비해 연성능력이 향상되었다.

핵 심 용 어 : PSRC 합성기둥, 앵글, 연속후프근, 선조립, 내진성능실험 